DOT/FAA/AM-07/4

Office of Aerospace Medicine

Washington, DC 20591

\title{
An Analysis of Preflight Weather Briefings
}

O. Veronika Prinzo

Civil Aerospace Medical Institute

Federal Aviation Administration

Oklahoma City, OK 73125

Alfred M. Hendrix

Ruby Hendrix

Hendrix \& Hendrix

Roswell, NM 88201

February 2007

Final Report 


\section{NOTICE}

This document is disseminated under the sponsorship of the U.S. Department of Transportation in the interest of information exchange. The United States Government assumes no liability for the contents thereof.

This publication and all Office of Aerospace Medicine technical reports are available in full-text from the Civil Aerospace Medical Institute's publications Web site: www.faa.gov/library/reports/medical/oamtechreports/index.cfm 
Technical Report Documentation Page

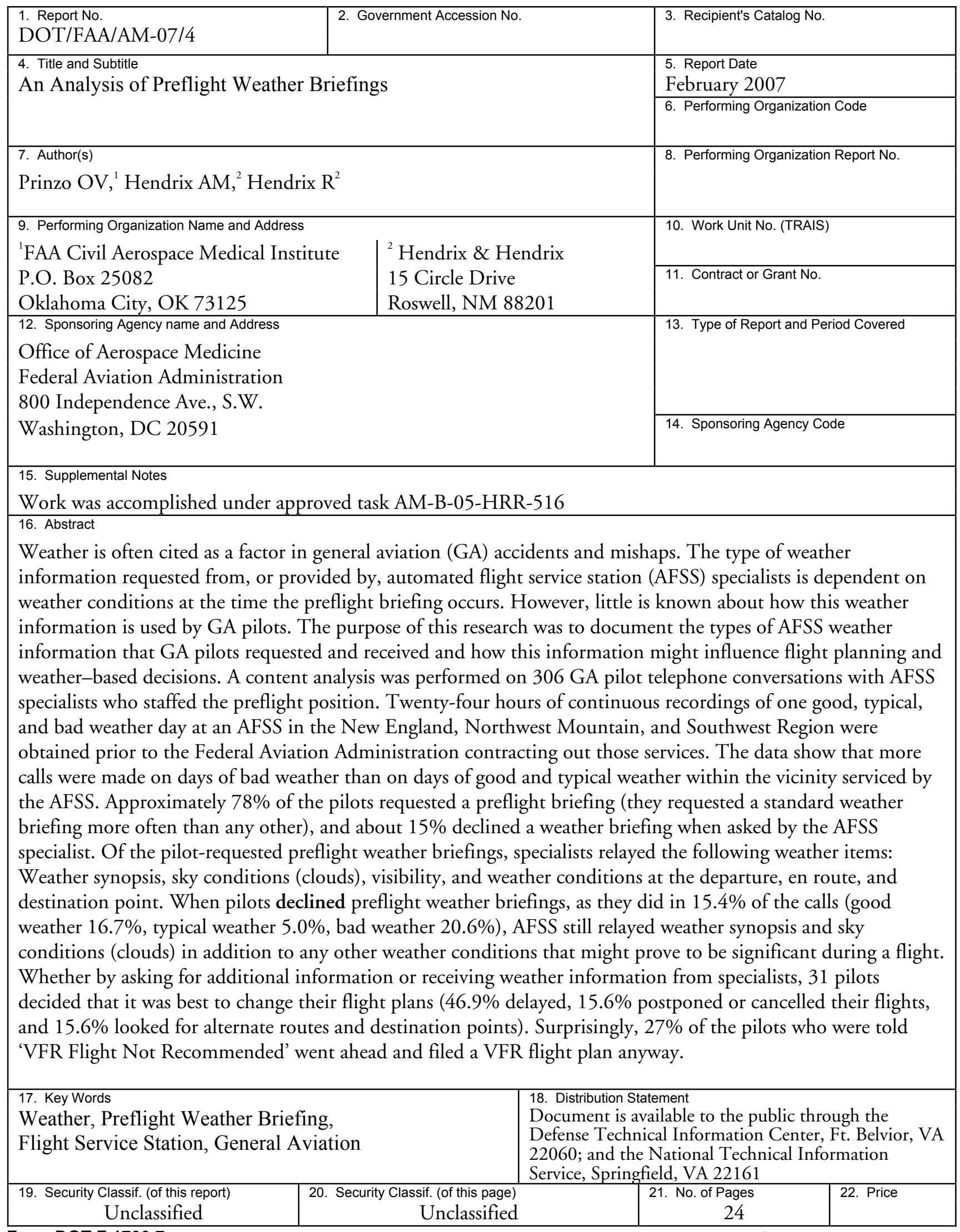

Form DOT F 1700.7 (8-72)

Reproduction of completed page authorized 



\section{ABBREVIATIONS \\ As used in this report, the following abbreviations/acronyms have the meanings indicated}

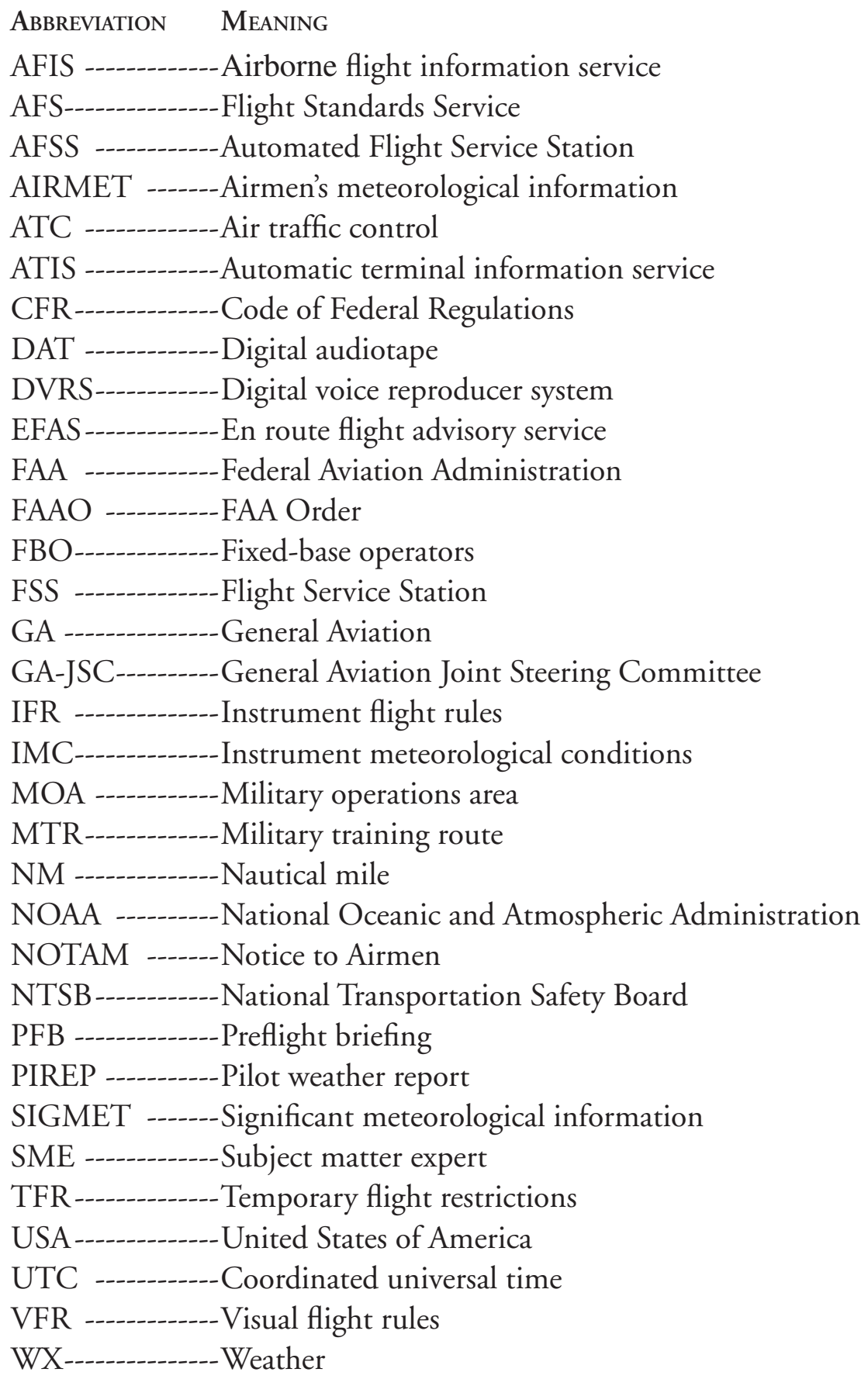





\title{
An Analysis of Preflight Weather Briefings
}

\author{
"... When it is evening, you say, 'It will be fair weather; for the sky is red.' \\ And in the morning, 'It will be stormy today, for the sky is red and threatening.'..." \\ -Matthew 16:2-3
}

Since its inception, the automated flight service station has evolved to be the single most widely used general aviation (GA) weather-information-provider. The Code of Federal Regulations (CFR) 14, Part 91.103 stipulates: "Each pilot in command shall, before beginning a flight, become familiar with all available information concerning that flight. This information must include- (a) For a flight under IFR or a flight not in the vicinity of an airport, weather reports and forecasts, ..." Unlike the 14 CFR for Part 121 (domestic, flag, and supplemental) and Part 135 (commuter and on demand) operators, the regulations for Part 91 (general aviation) operators do not stipulate that GA pilots must contact a particular approved source for weather information. They can acquire any weather information in real-time from a multitude of sources that include television, radio, Internet, and AFSS or by simply going outside and looking at the sky conditions. ${ }^{1}$

In preparation for a flight, GA pilots can call their local AFSS to receive standard, abbreviated, and outlook preflight briefings. AFSS specialists provide them with local, en route, and destination weather information to aid route planning and go/no go decision-making when faced with possible adverse weather. Generally, the first contact by a GA pilot is with the Preflight position, where either a visual flight rules (VFR) or instrument flight rules (IFR) flight plan is filed and requests are made for any specific information. The Preflight position then would relay a briefing of items outlined in FAAO 7110.10R Flight Services $\$ 3-2-1$ through $\$ 3-2-3$ (Federal Aviation Administration, 2004).

After departure, a GA pilot flying a VFR aircraft could use airborne flight information service $\left(A F I S^{2}\right)$, but would normally contact the AFSS Inflight/Flight Watch position for additional weather information. The pilot of an IFR aircraft may also contact an AFSS Inflight specialist, use AFIS to receive weather information, or speak directly with an ATC specialist at a Terminal Radar Approach Control or En route Air Traffic Control facility.

\footnotetext{
${ }^{1}$ For a record of the source of weather information to be available, pilots must contact an AFSS, use DUATs, or use a commercial weather service provider.

${ }^{2}$ AFIS included any automated weather reports other than an AFSS or any other air traffic control facility. It included airborne systems, DUATS, etc.
}

Although the focus of this report is on the preflight weather briefings, the availability of weather information during actual flights is worthy of a separate study. In particular, accident data show that the number of in-flight contacts with AFSS, even by pilots ultimately involved in fatal weather accidents, averages $3 \%$ of the accident flights (Lenz 2006) ${ }^{3}$. According to Lenz it is this tactical information that is vital to pilots for avoiding weather hazard areas during IFR and VFR flights. Given the rapid and immediate access to, and availability of, weather information, it is surprising that weather still is listed as a causal or contributing factor in 30\% to $35 \%$ of aviation accidents and incidents (Pearson, 2002). For a comprehensive review and summary of the NTSB accident reports involving fixed-wing general aviation aircraft weighing 12,500 pounds or less see the Nall Report (Aircraft Owners and Pilots Association Fight Safety Foundation 2005).

The Federal Aviation Administration (FAA) Flight Standards Service (AFS) General Aviation and Commercial Division's mission has initiated numerous GA safety programs in response to recommendations made by the National Transportation Safety Board (NTSB, 1968, 1974, 1976, 1989, 2005) regarding weather and pilot decision-making. The FAA-Industry General Aviation Joint Steering Committee (GA-JSC) has focused heavily on ways to mitigate accidents involving weather and pilot decision-making. FAA-sponsored research activities are attempting to identify the factors that give rise to GA pilots flying into instrument meteorological conditions.

For example, Driskill, Weissmuller, Quebe, Hand, Dittmar, and Hunter (1997) conducted a study to examine how pilots evaluate weather and terrain information in preparation of a flight. They had 150 pilots (age: 18-79 yrs) (flight time: 6-26,500 hrs) read three sets of 27 different weather scenarios, sort them from least to most comfortable about completing the flight, and assign a comfort rating to each one. Each scenario within a set was unique with respect to precipitation (light rain, moderate rain, heavy snow), visibility (1 NM, 4 NM, 8 $\mathrm{NM})$, and ceiling $(800 \mathrm{ft}, 1800 \mathrm{ft}, 4000 \mathrm{ft})$ and, when

\footnotetext{
${ }^{3}$ All references to Lenz are from personal communication with him in June 2006. Michael Lenz was with the FAA's Office of System Safety and is currently with the FAA's General Aviation and Commercial Division.
} 
combined, they were plausible according to evaluations performed by weather experts. The weather scenarios were representative of three cross-country flights that varied in terrain (water: Great Lakes, non-mountainous: North Texas, mountainous: New Mexico). The major finding was that pilots consistently used the available weather information to determine the safety risk associated with VFR flights for all weather and terrain conditions. However, pilots differed in their degree of comfort with the presented weather scenarios when faced with flying over different terrains. Driskill et al. suggested that pilots might differentially weigh weather information according to terrain such that higher values (e.g., high visibility) compensated for lower values in others (e.g., low ceiling) for non-mountainous terrains but not for flights that involved mountainous terrains (they might use an absolute value for the decision point).

More recently, Knecht, Harris, and Shappell (2005) performed a simulation study that also examined weatherrelated pilot decision-making. In their study, pilots were provided with a hypothetical situation in which they were to transport a piece of equipment from an uncontrolled airfield near Oklahoma City, OK, to an oilfield near Amarillo, TX. The equipment was crucial to bring oil production back on-line. The low-incentive pilots were told that they were paid on a per-hour basis and would be paid regardless of their fly/no fly decision. Pilots in the high-incentive group received a sizeable bonus for immediate takeoff that decreased incrementally with every 30-min delay. In preparation for the VFR flight, all pilots received the same current weather report that included marginal visibility ( $1 \mathrm{sm}, 3 \mathrm{sm}, 5 \mathrm{sm}$ ) and cloud ceiling $(1000 \mathrm{ft}, 2000 \mathrm{ft})$. After receiving the weather report, they had to decide whether to fly, wait and try later, or cancel the flight. Those pilots choosing to wait received updated weather reports every $30 \mathrm{~min}$ until they either flew or two hours elapsed at which time the experiment ended (the weather never improved beyond marginal visibility). Like the findings reported by Driskell et al., the results of Knecht et al. suggested that pilots consider both the visibility and cloud ceiling(s) when deciding whether or not to fly. It may be that their value judgments became compromised when presented with external pressures such as a financial bonus (as evidenced with a tendency toward longer decision times when compared with pilots who were not offered a bonus). Since the vast majority of weather-related, fatal accidents occur on cross-country flights, these pressures are always present on actual flights (Lenz 2006).

Although informative, neither study included dynamic communication opportunities between the pilots and AFSS personnel (or access to other sources of weather information). Inasmuch as the most recent NTSB safety study (2005) reported that in $66 \%$ of the fatal and $58 \%$ of the non-fatal accidents, pilots received preflight weather information from an AFSS before their flights, it did not report on the quality of the information that these pilots received. Consequently, little is known about the information obtained from the AFSS and its influence on pilot decision-making during preflight preparations. While the types of services that AFSS provide are listed in the FAA publication FAAO 7110.10R Flight Services, data are not available as to either the frequency that these services are provided to pilots or the types of weather information pilots receive that might help mitigate GA fatal accidents related to weather or visibility. This is worthy of further study as related to accidents.

This study examined the communications that took place between the AFSS specialists staffing the Preflight position and pilots who called in on the telephone. The data were used to develop baseline descriptive statistics to describe the frequency of occurrence and content of preflight briefings with a special emphasis on documenting the types of weather information that pilots request and might use when planning a flight or making weather-based decisions. Specifically, we conducted a verbal content analysis on time-stamped digital audiotape (DAT) recordings that were obtained from FAA-operated AFSSs in the New England, Northwest Mountain, and Southwest Regions. In particular, preflight standard, abbreviated, and outlook weather briefings were examined that represented a good, typical, and bad weather day occurring around the area serviced by each of the three AFSS.

\section{METHOD}

\section{Materials}

Audiotapes. One AFSS in the New England, Northwest Mountain, and Southwest Region was contacted and asked to provide 24 hours of continuous DAT recordings that best represented a good, typical, and bad weather day at and around their facility. Each DAT contained separate voice records of all communication transmitted on the radio frequency assigned to a particular sector position on the left channel. The right channel contained the Coordinated Universal Time (UTC) time code. The NiceLogger ${ }^{\mathrm{TM}}$ Digital Voice Reproducer System (DVRS) decoded, displayed, and correlated time with the voice stream in real time. Presented in Table 1 are the dates and times of those recordings.

AFSS Communication Spreadsheet. Five areas of information were identified and recorded: Facility Information included briefing number, the name of the facility, sector/position identifier, an assigned AFSS specialist identifier, DAT time sample, the onset of preflight briefing in UTC (hr:min:sec), proposed departure time, 
Table 1. AFSS sampled according to date and time (Local and UTC)

\begin{tabular}{lll}
\hline FAA Region / Weather & Date and Local Time & Date and UTC (Zulu Time) \\
\hline $\begin{array}{l}\text { New England } \\
\text { Good }\end{array}$ & $06 / 02 / 050000$ to $06 / 02 / 052359$ & $06 / 02 / 050400$ to $06 / 03 / 050359$ \\
$\quad$ Typical & $06 / 17 / 050000$ to $06 / 17 / 052359$ & $06 / 17 / 050400$ to $06 / 18 / 050359$ \\
$\quad$ Bad & $06 / 16 / 050000$ to $06 / 16 / 052359$ & $06 / 16 / 050400$ to $06 / 17 / 050359$ \\
Northwest Mountain & & \\
$\quad$ Good & $05 / 27 / 050500$ to $05 / 29 / 050500 \mathrm{~L}$ & $05 / 27 / 051200$ to $05 / 29 / 051200 Z$ \\
$\quad$ Typical & $05 / 29 / 050500$ to $05 / 31 / 050500 \mathrm{~L}$ & $05 / 29 / 051200$ to $05 / 31 / 051200 Z$ \\
$\quad$ Bad & $05 / 31 / 050500$ to $06 / 02 / 050500 \mathrm{~L}$ & $05 / 31 / 051200$ to $06 / 02 / 051200 Z$ \\
Southwest & & \\
Good & $06 / 12 / 050000$ to $06 / 12 / 052359 \mathrm{~L}$ & $06 / 12 / 050500$ to $06 / 13 / 050459 Z$ \\
Typical & $06 / 11 / 050000$ to $06 / 11 / 052359 \mathrm{~L}$ & $06 / 11 / 050500$ to $06 / 12 / 050459 Z$ \\
Bad & $06 / 10 / 050000$ to $06 / 10 / 052359 \mathrm{~L}$ & $06 / 10 / 050500$ to $06 / 11 / 050459 Z$ \\
\hline
\end{tabular}

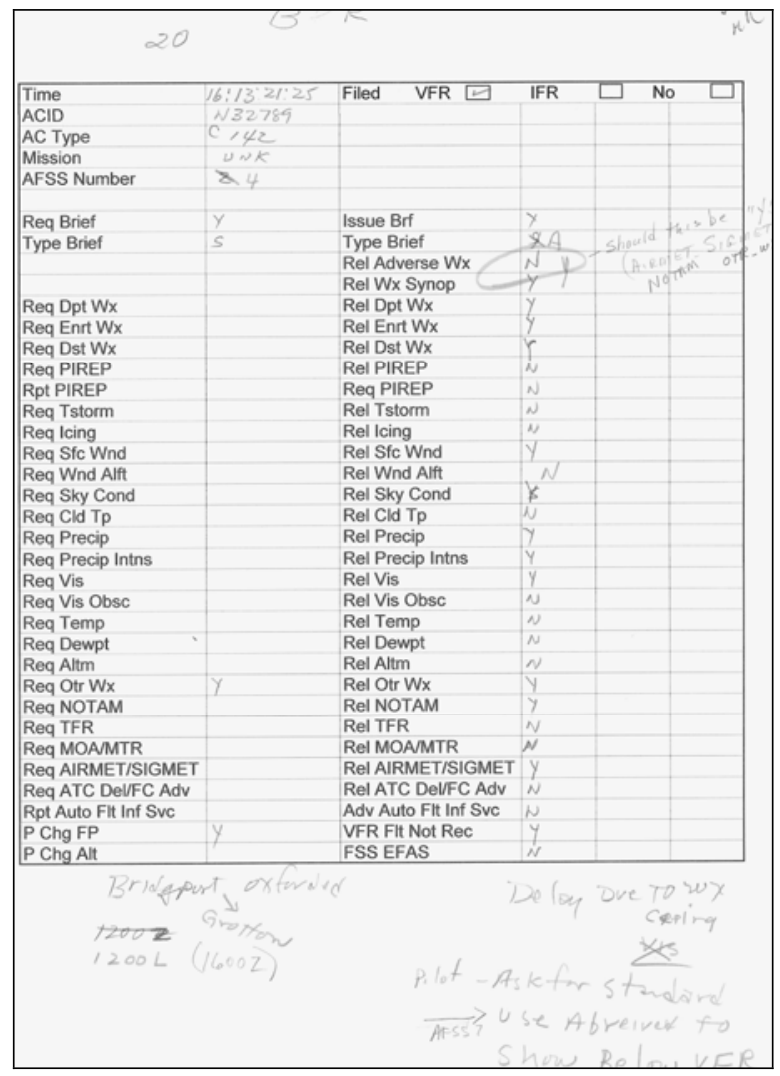

Figure 1. An example of a completed form containing pilot and AFSS specialist communications 
Table 2. Number of calls made to each AFSS according to weather

\begin{tabular}{lrcrr}
\hline \multirow{2}{*}{ Weather } & \multicolumn{3}{c}{ FAA Region } & \multirow{2}{*}{ Total } \\
\cline { 2 - 4 } & New England & $\begin{array}{l}\text { Northwest } \\
\text { Mountain }\end{array}$ & Southwest & $83(90)$ \\
\hline Good & $28(30)$ & $30(30)$ & $25(30)$ & $76(80)$ \\
Typical & $29(30)$ & $18(20)$ & $29(30)$ & $127(136)$ \\
Bad & $41(46)$ & $45(45)$ & $41(45)$ & $286(306)$ \\
Total & $98(106)$ & $93(95)$ & $95(105)$ & \\
\hline
\end{tabular}

and weather. Aircraft Information contained the call sign, type of aircraft, and any weather-related avionics equipment aboard ${ }^{4}$. Flight Information recorded whether the pilot filed a flight plan, the type flight plan, whether it was a day or night flight, the purpose of the flight, and the method of communication with the AFSS. Pilot Requests/Reports involved whether the pilot requested a preflight briefing, the type preflight briefing, the specific weather, NOTAMs, TFRs, special airspace activity, other weather information, and whether the preflight briefing altered the pilot's intention to fly. AFSS Preflight Information provided for the encoding of type of briefing, specific weather, NOTAMs, TFRs, special use airspace, other information related to the safety of the flight, and whether VFR flight was not recommended. Presented in Appendix A is a description of the Excel spreadsheet that was developed to record/encode this data. It allows for the inclusion of communications between the pilot and Inflight and Flight Watch positions.

\section{Subject Matter Expert (SME)}

The SME (a co-author of this report) was an instrument-rated pilot and former air traffic controller who had worked as an FAA Academy instructor for 8 years and had worked for 12 years in FAA supervision and management. This individual had previously encoded over 50,000 ATC messages, suggesting that he was highly familiar and expert in the extraction and codification of verbal messages.

\section{Procedure}

The SME was provided with, and trained on, one DVRS and received the most recent version of FAAO 7110.10R Flight Services. It guided the development of the AFSS communication spreadsheet. The SME also was instructed on whom to contact at each AFSS facility, should additional information be needed (e.g., call-sign identifiers, routes).

\footnotetext{
${ }^{4}$ This information was provided by the pilots when talking with the AFSS specialist.
}

The SME listened to a voice sample stored on the DVRS and developed a form to record the types of information exchanged between pilots and AFSS specialist. While listening a second time, the SME recorded the contents of each transmission onto the data entry form such as the one displayed in Figure 1.

During a third pass, the accuracy of the encodings was evaluated, and if correct, left alone. In some instances additional information was added while, in others, values were corrected to reflect what was spoken. These data were entered onto the EXCEL spreadsheets and verified by the SME and data entry clerk. If, during error checking, a discrepancy was found, they went to the DVRS and listened yet again to the time sample that correlated with the message and data point in question.

The EXCEL spreadsheets were imported into SPSS $\mathrm{x}$ and combined to create a master database. The data were once again subjected to error checking, and only three data points were corrected.

\section{RESULTS}

As shown in Table 2, the recordings represented 306 calls made on good, typical, and poor weather days occurring in the New England, Southwest, and Northwest Mountain Regions. ${ }^{5}$ Each cell in the table represents the number of calls according to the aircraft call sign (not in parentheses) made to the AFSS on a particular day and total number of calls (in parentheses). Not surprisingly, more unique calls were made on days with bad weather than on good and typical weather days, $\chi^{2}(2)=16.03$, $\mathrm{p} \leq .05$ and the geographical location of the FAA AFSS did not matter, $\chi^{2}(2)=0.13$.

The SME listened to the tapes and documented whether the pilot requested (239) or declined (47) a preflight briefing (PFB). He also recorded the types of

\footnotetext{
5 To meet the assumptions of the Chi-Square test, 10 pilots made more than one call to an AFSS. Their calls were not included in the statistical analysis, thereby reducing the number of unique calls to 286.
} 
Table 3. Type of preflight weather briefing requested according to the type of flight plan filed

\begin{tabular}{lccccc}
\hline & \multicolumn{4}{c}{ Type of Preflight Weather Briefing Requested } & \\
\cline { 2 - 5 } Flight Plan & Standard & Abbreviated & Outlook & None & Total \\
\hline VFR & 72 & 63 & 22 & 9 & 166 \\
IFR & 39 & 35 & 8 & 38 & 120 \\
Total & 111 & 98 & 30 & 47 & 286 \\
\hline
\end{tabular}

weather information requested by pilots or provided by the AFSS specialists.

The pilots generally fell into three basic groups. 1) Local fliers; training schools, students, aircraft buffs, and "hole borers" that stay within 30-50 miles of the departure point and return to that airport. This group made up a large part of the VFR briefings. 2) Fixed-base operators (FBOs) who rent aircraft and transport passengers for hire, advanced training, and short distance carriers (with stored or pre-filed flight plans), and pilots of larger aircraft. There appeared to be approximately $60 \%$ VFR and 40\% IFR pilots. 3) Business, military (training and operations), corporate, and long-distance lifeguard pilots who probably will be looking at Internet aviation weather services while discussing the preflight briefing with the AFSS specialist.

As shown in Table 3, an examination of the type of flight plan filed revealed that the VFR pilots requested standard weather briefings more often than either abbreviated, outlook, or no briefings $\chi^{2}(3)=68.17, \mathrm{p} \leq$ .05 . On the other hand, IFR pilots seemed to request standard and abbreviated briefings to a greater extent than outlook briefings and no weather briefings more often than outlook briefings $\chi^{2}(3)=21.80, \mathrm{p} \leq .05$.

The data presented in Tables 4-5 show that, regardless of weather conditions, of the pilot-requested preflight weather briefings, AFSS specialists relayed the following weather items: Weather synopsis, sky conditions (clouds), visibility, weather conditions at the departure, en route, and destination point. More detailed weather data were passed during periods of adverse weather. Although used to a lesser degree, these data included adverse conditions, altimeter, cloud tops, dew point, icing conditions, surface winds, winds aloft, temperature, thunderstorm activity, precipitation, precipitation intensity, visibility obscuration, other weather, PIREP, AIRMET/SIGMET, MOA, MTR, NOTAMs, and TFRs (see abbreviations).

When pilots requested preflight briefings on a good weather day, AFSS specialists relayed weather synopsis, sky conditions, visibility, as well as the weather conditions at the departure point, en route weather conditions, and weather at the destination approximately $75 \%-85 \%$ of the time with surface winds included $73.3 \%$. During these briefings, pilots tended to request sky conditions, winds aloft, and NOTAMs to a greater extent than to request the weather at the destination point or en route. They were even less likely to request visibility, surface winds, or upper level winds. Pilots never requested precipitation intensity, icing conditions, altimeter, or TFRs.

On a typical weather day, as part of a requested preflight briefing, AFSS specialists relayed sky conditions, provided a weather synopsis, as well as relayed the weather conditions at the departure, en route, and destination points between $86.8 \%$ to more than $93 \%$ of the time. To a lesser extent $(76.3 \%-51.3 \%)$, they also provided surface winds, visibility, adverse conditions, thunderstorm activity, and NOTAMs. Pilots, in turn, asked about the en route weather, sky conditions, and weather at the destination point, followed by requests for TFRs, weather conditions at the departure point, and NOTAMs. They never requested visibility obscuration, temperature, dew point, precipitation intensity, or altimeter information.

Finally, on bad weather days, as part of a requested preflight briefing, AFSS specialists relayed the sky conditions, provided a weather synopsis, relayed adverse conditions, provided weather information at the departure, en route, and destination points, and surface winds during $80.6 \%$ - $89.9 \%$ of the briefings. At least $50 \%$ of these briefings also included visibility, AIRMET/SIGMET, precipitation, and winds aloft information. Pilots, in turn, requested the weather at their destination point, followed by en route conditions, weather at the departure point, and winds aloft. They never asked about ATC delays, visibility obscuration, the temperature, or dew point.

When pilots declined preflight weather briefings, as they did in $15.4 \%$ of the calls (good weather $16.7 \%$, typical weather $5.0 \%$, bad weather $20.6 \%$ ), AFSS specialists still relayed weather synopsis and sky conditions (clouds), in addition to any other weather conditions that might prove to be significant during a flight. During these briefings, on good weather days some pilots asked about the weather at their destination points, TFRs, thunderstorm activity, and en route weather conditions. On typical weather days, conversations included weather conditions at the point of departure, en route, and at the destination, in addition to winds aloft, thunderstorm activity 
Table 4. Percentage of pilot-requested/reported weather information as a function of whether a preflight weather briefing was or was not requested by the pilot

\begin{tabular}{|c|c|c|c|c|c|c|}
\hline \multirow{3}{*}{$\begin{array}{l}\text { Type of Pilot- } \\
\text { Requested/Reported } \\
\text { Weather Information }\end{array}$} & \multicolumn{6}{|c|}{ Type of Weather Day for AFSS } \\
\hline & \multicolumn{2}{|c|}{ Good } & \multicolumn{2}{|c|}{ Typical } & \multicolumn{2}{|c|}{$\mathrm{Bad}$} \\
\hline & $\begin{array}{c}\text { PFB } \\
\text { Requested }^{1}\end{array}$ & $\begin{array}{l}\text { PFB Not } \\
\text { Requested }\end{array}$ & $\begin{array}{c}\text { PFB } \\
\text { Requested }\end{array}$ & $\begin{array}{l}\text { PFB Not } \\
\text { Requested }\end{array}$ & $\begin{array}{c}\text { PFB } \\
\text { Requested }\end{array}$ & $\begin{array}{l}\text { PFB Not } \\
\text { Requested }\end{array}$ \\
\hline $\begin{array}{l}\text { Did pilot report having } \\
\text { AFIS }^{2}\end{array}$ & $25.3 \%$ & $13.3 \%$ & $17.1 \%$ & $0.0 \%$ & $26.9 \%$ & $25.0 \%$ \\
\hline $\begin{array}{l}\text { Did pilot request destination } \\
\text { WX }\end{array}$ & $18.7 \%$ & $6.7 \%$ & $23.7 \%$ & $25.0 \%$ & $27.8 \%$ & $0.0 \%$ \\
\hline Did pilot request TFRs & $2.7 \%$ & $6.7 \%$ & $19.7 \%$ & $0.0 \%$ & $10.2 \%$ & $10.7 \%$ \\
\hline $\begin{array}{l}\text { Did pilot request } \\
\text { thunderstorm activity }\end{array}$ & $1.3 \%$ & $6.7 \%$ & $1.3 \%$ & $0.0 \%$ & $3.7 \%$ & $3.6 \%$ \\
\hline Did pilot request winds aloft & $24.0 \%$ & $0.0 \%$ & $10.5 \%$ & $25.0 \%$ & $14.8 \%$ & $3.6 \%$ \\
\hline $\begin{array}{l}\text { Did pilot request en route } \\
\text { WX conditions }\end{array}$ & $14.7 \%$ & $0.0 \%$ & $26.3 \%$ & $25.0 \%$ & $23.1 \%$ & $0.0 \%$ \\
\hline $\begin{array}{l}\text { Did pilot request WX } \\
\text { conditions at departure point }\end{array}$ & $13.3 \%$ & $0.0 \%$ & $15.8 \%$ & $25.0 \%$ & $21.3 \%$ & $0.0 \%$ \\
\hline Did pilot request other WX & $0.0 \%$ & $0.0 \%$ & $7.9 \%$ & $25.0 \%$ & $12.0 \%$ & $0.0 \%$ \\
\hline $\begin{array}{l}\text { Did pilot report } \\
\text { thunderstorm activity }\end{array}$ & $8.0 \%$ & $0.0 \%$ & $14.5 \%$ & $25.0 \%$ & $9.3 \%$ & $0.0 \%$ \\
\hline Did pilot request NOTAMs & $20.0 \%$ & $0.0 \%$ & $14.5 \%$ & $0.0 \%$ & $13.0 \%$ & $7.1 \%$ \\
\hline $\begin{array}{l}\text { Did pilot request } \\
\text { AIRMET/SIGMET }\end{array}$ & $4.0 \%$ & $0.0 \%$ & $3.9 \%$ & $0.0 \%$ & $11.1 \%$ & $3.6 \%$ \\
\hline Did pilot request PIREP & $4.0 \%$ & $0.0 \%$ & $1.3 \%$ & $0.0 \%$ & $0.9 \%$ & $3.6 \%$ \\
\hline Did pilot request cloud tops & $1.3 \%$ & $0.0 \%$ & $6.6 \%$ & $0.0 \%$ & $5.6 \%$ & $3.6 \%$ \\
\hline $\begin{array}{l}\text { Did pilot request ATC } \\
\text { delays or flow control } \\
\text { advisories }\end{array}$ & $0.0 \%$ & $0.0 \%$ & $2.6 \%$ & $0.0 \%$ & $0.0 \%$ & $3.6 \%$ \\
\hline $\begin{array}{l}\text { Did pilot request icing } \\
\text { conditions }\end{array}$ & $0.0 \%$ & $0.0 \%$ & $1.3 \%$ & $0.0 \%$ & $3.7 \%$ & $3.6 \%$ \\
\hline $\begin{array}{l}\text { Did pilot request sky } \\
\text { conditions (clouds) }\end{array}$ & $25.3 \%$ & $0.0 \%$ & $25.0 \%$ & $0.0 \%$ & $12.0 \%$ & $0.0 \%$ \\
\hline Did pilot request visibility & $12.0 \%$ & $0.0 \%$ & $10.5 \%$ & $0.0 \%$ & $2.8 \%$ & $0.0 \%$ \\
\hline $\begin{array}{l}\text { Did pilot request surface } \\
\text { winds }\end{array}$ & $9.3 \%$ & $0.0 \%$ & $6.6 \%$ & $0.0 \%$ & $12.0 \%$ & $0.0 \%$ \\
\hline $\begin{array}{l}\text { Did pilot request MOA or } \\
\text { MTR }\end{array}$ & $4.0 \%$ & $0.0 \%$ & $1.3 \%$ & $0.0 \%$ & $0.9 \%$ & $0.0 \%$ \\
\hline $\begin{array}{l}\text { Did pilot request } \\
\text { precipitation }\end{array}$ & $2.7 \%$ & $0.0 \%$ & $7.9 \%$ & $0.0 \%$ & $4.6 \%$ & $0.0 \%$ \\
\hline $\begin{array}{l}\text { Did pilot request visibility } \\
\text { obscuration }\end{array}$ & $1.3 \%$ & $0.0 \%$ & $0.0 \%$ & $0.0 \%$ & $0.0 \%$ & $0.0 \%$ \\
\hline $\begin{array}{l}\text { Did pilot request } \\
\text { temperature }\end{array}$ & $1.3 \%$ & $0.0 \%$ & $0.0 \%$ & $0.0 \%$ & $0.0 \%$ & $0.0 \%$ \\
\hline Did pilot request dew point & $1.3 \%$ & $0.0 \%$ & $0.0 \%$ & $0.0 \%$ & $0.0 \%$ & $0.0 \%$ \\
\hline $\begin{array}{l}\text { Did pilot request } \\
\text { precipitation intensity }\end{array}$ & $0.0 \%$ & $0.0 \%$ & $0.0 \%$ & $0.0 \%$ & $1.9 \%$ & $0.0 \%$ \\
\hline Did pilot request altimeter & $0.0 \%$ & $0.0 \%$ & $0.0 \%$ & $0.0 \%$ & $0.9 \%$ & $0.0 \%$ \\
\hline
\end{tabular}

\footnotetext{
${ }^{1}$ The number of pilot preflight briefing (PFB) is:

Good WX Requested $=75$, Good WX Not Requested $=15$; Typical WX Requested $=76$, Typical WX Not Requested $=4$; Bad WX Requested $=108$, Bad WX Not Requested $=28$.
}

${ }^{2}$ AFIS is a data link aircraft flight information service that offers graphical and text weather data to pilots. 
Table 5. Percentage of AFSS-relayed/reported weather information as a function of whether a preflight weather briefing was or was not requested by the pilot

\begin{tabular}{|c|c|c|c|c|c|c|}
\hline \multirow{3}{*}{$\begin{array}{l}\text { Type of AFSS } \\
\text { Relayed/Requested } \\
\text { Weather Information }\end{array}$} & \multicolumn{6}{|c|}{ Type of Weather Day for AFSS } \\
\hline & \multicolumn{2}{|c|}{ Good } & \multicolumn{2}{|c|}{ Typical } & \multicolumn{2}{|c|}{$\mathrm{Bad}$} \\
\hline & $\begin{array}{c}\text { PFB } \\
\text { Requested }\end{array}$ & $\begin{array}{l}\text { PFB Not } \\
\text { Request }\end{array}$ & $\begin{array}{c}\text { PFB } \\
\text { Requested }\end{array}$ & $\begin{array}{l}\text { PFB Not } \\
\text { Requested }\end{array}$ & $\begin{array}{c}\text { PFB } \\
\text { Requested }\end{array}$ & $\begin{array}{l}\text { PFB Not } \\
\text { Request }\end{array}$ \\
\hline Did AFSS relay WX synopsis & $86.7 \%$ & $6.7 \%$ & $92.1 \%$ & $50.0 \%$ & $88.0 \%$ & $3.6 \%$ \\
\hline $\begin{array}{l}\text { Did AFSS relay sky } \\
\text { conditions (clouds) }\end{array}$ & $85.3 \%$ & $6.7 \%$ & $93.4 \%$ & $25.0 \%$ & $88.9 \%$ & $3.6 \%$ \\
\hline Did AFSS relay visibility & $81.3 \%$ & $0.0 \%$ & $73.7 \%$ & $25.0 \%$ & $71.3 \%$ & $3.6 \%$ \\
\hline $\begin{array}{l}\text { Did AFSS relay destination } \\
\text { WX }\end{array}$ & $78.7 \%$ & $6.7 \%$ & $92.1 \%$ & $0.0 \%$ & $87.0 \%$ & $3.6 \%$ \\
\hline $\begin{array}{l}\text { Did AFSS relay en route WX } \\
\text { conditions }\end{array}$ & $78.7 \%$ & $0.0 \%$ & $89.5 \%$ & $25.0 \%$ & $87.0 \%$ & $3.6 \%$ \\
\hline $\begin{array}{l}\text { Did AFSS relay WX } \\
\text { conditions at departure point }\end{array}$ & $74.7 \%$ & $6.7 \%$ & $86.8 \%$ & $0.0 \%$ & $83.3 \%$ & $3.6 \%$ \\
\hline $\begin{array}{l}\text { Did AFSS relay surface } \\
\text { winds }\end{array}$ & $73.3 \%$ & $0.0 \%$ & $76.3 \%$ & $25.0 \%$ & $80.6 \%$ & $3.6 \%$ \\
\hline $\begin{array}{l}\text { Did AFSS relay adverse } \\
\text { conditions }\end{array}$ & $69.3 \%$ & $0.0 \%$ & $68.4 \%$ & $25.0 \%$ & $88.0 \%$ & $21.4 \%$ \\
\hline Did AFSS relay NOTAMs & $62.7 \%$ & $0.0 \%$ & $51.3 \%$ & $0.0 \%$ & $49.1 \%$ & $14.3 \%$ \\
\hline Did AFSS relay winds aloft & $54.7 \%$ & $0.0 \%$ & $42.1 \%$ & $0.0 \%$ & $51.9 \%$ & $3.6 \%$ \\
\hline $\begin{array}{l}\text { Did AFSS relay } \\
\text { AIRMET/SIGMET }\end{array}$ & $41.3 \%$ & $6.7 \%$ & $31.6 \%$ & $25.0 \%$ & $61.1 \%$ & $21.4 \%$ \\
\hline Did AFSS relay temperature & $36.0 \%$ & $0.0 \%$ & $17.1 \%$ & $0.0 \%$ & $40.7 \%$ & $0.0 \%$ \\
\hline $\begin{array}{l}\text { Did AFSS relay thunderstorm } \\
\text { activity }\end{array}$ & $29.3 \%$ & $0.0 \%$ & $52.6 \%$ & $50.0 \%$ & $47.2 \%$ & $7.1 \%$ \\
\hline Did AFSS relay precipitation & $26.7 \%$ & $6.7 \%$ & $38.2 \%$ & $25.0 \%$ & $54.6 \%$ & $3.6 \%$ \\
\hline Did AFSS relay altimeter & $25.3 \%$ & $0.0 \%$ & $7.9 \%$ & $0.0 \%$ & $11.1 \%$ & $0.0 \%$ \\
\hline Did AFSS relay cloud tops & $22.7 \%$ & $0.0 \%$ & $38.2 \%$ & $25.0 \%$ & $25.0 \%$ & $3.6 \%$ \\
\hline $\begin{array}{l}\text { Did AFSS relay visibility } \\
\text { obscuration }\end{array}$ & $16.0 \%$ & $0.0 \%$ & $15.8 \%$ & $0.0 \%$ & $13.0 \%$ & $0.0 \%$ \\
\hline Did AFSS relay TFRs & $16.0 \%$ & $6.7 \%$ & $47.4 \%$ & $0.0 \%$ & $29.6 \%$ & $17.9 \%$ \\
\hline Did AFSS relay other WX & $9.3 \%$ & $0.0 \%$ & $18.4 \%$ & $25.0 \%$ & $43.5 \%$ & $21.4 \%$ \\
\hline Did AFSS relay PIREP & $8.0 \%$ & $0.0 \%$ & $22.4 \%$ & $0.0 \%$ & $33.3 \%$ & $3.6 \%$ \\
\hline $\begin{array}{l}\text { Did AFSS relay precipitation } \\
\text { intensity }\end{array}$ & $8.0 \%$ & $6.7 \%$ & $10.5 \%$ & $25.0 \%$ & $33.3 \%$ & $3.6 \%$ \\
\hline Did AFSS relay dew point & $5.3 \%$ & $0.0 \%$ & $10.5 \%$ & $0.0 \%$ & $20.4 \%$ & $0.0 \%$ \\
\hline $\begin{array}{l}\text { Did AFSS relay MOA or } \\
\text { MTR }\end{array}$ & $5.3 \%$ & $0.0 \%$ & $2.6 \%$ & $0.0 \%$ & $3.7 \%$ & $0.0 \%$ \\
\hline $\begin{array}{l}\text { Did AFSS relay icing } \\
\text { conditions }\end{array}$ & $1.3 \%$ & $0.0 \%$ & $1.3 \%$ & $0.0 \%$ & $25.9 \%$ & $17.9 \%$ \\
\hline $\begin{array}{l}\text { Did AFSS relay ATC delays } \\
\text { or flow control advisories }\end{array}$ & $1.3 \%$ & $0.0 \%$ & $0.0 \%$ & $0.0 \%$ & $2.8 \%$ & $3.6 \%$ \\
\hline $\begin{array}{l}\text { Did AFSS advise EFAS } \\
\text { available }\end{array}$ & $8.0 \%$ & $20.0 \%$ & $22.4 \%$ & $50.0 \%$ & $15.7 \%$ & $17.9 \%$ \\
\hline $\begin{array}{l}\text { Did AFSS advise current } \\
\text { AFIS }\end{array}$ & $20.0 \%$ & $13.3 \%$ & $15.8 \%$ & $0.0 \%$ & $21.3 \%$ & $14.3 \%$ \\
\hline Did AFSS request PIREP & $54.7 \%$ & $53.3 \%$ & $36.8 \%$ & $25.0 \%$ & $39.8 \%$ & $21.4 \%$ \\
\hline $\begin{array}{l}\text { Did AFSS state VFR flight } \\
\text { not recommended }\end{array}$ & $10.7 \%$ & $0.0 \%$ & $6.6 \%$ & $0.0 \%$ & $10.2 \%$ & $0.0 \%$ \\
\hline Did pilot change flight plan & $0.0 \%$ & $0.0 \%$ & $14.5 \%$ & $0.0 \%$ & $15.7 \%$ & $0.0 \%$ \\
\hline Did pilot change altitude & $21.3 \%$ & $0.0 \%$ & $1.3 \%$ & $0.0 \%$ & $0.0 \%$ & $0.0 \%$ \\
\hline
\end{tabular}


Table 6. Outcome of AFSS specialist preflight weather briefing on pilot flight plan decision making*

\begin{tabular}{|c|c|c|c|c|}
\hline \multirow[b]{2}{*}{ Outcome } & \multicolumn{3}{|c|}{ Type of Weather } & \multirow[b]{2}{*}{ Total } \\
\hline & Good & Typical & $\mathrm{Bad}$ & \\
\hline \multicolumn{5}{|l|}{ Pilot changed the flight plan } \\
\hline VFR Filed Flight Plan & $(2.01 \%) \quad 5$ & $(3.51 \%) 8$ & $(2.89 \%) 11$ & 24 \\
\hline IFR Filed Flight Plan & $(0.40 \%) \quad 1$ & $(0.44 \%) \quad 1$ & $(1.31 \%) \quad 5$ & 7 \\
\hline \multicolumn{5}{|c|}{ Pilot did not change the flight plan } \\
\hline VFR Filed Flight Plan & $(20.08 \%) 50$ & $(18.42 \%) 42$ & $(13.12 \%) 50$ & 142 \\
\hline IFR Filed Flight Plan & $(10.84 \%) 27$ & $(10.96 \%) 25$ & $(16.01 \%) 61$ & 113 \\
\hline Total & 83 & 76 & 127 & 286 \\
\hline
\end{tabular}

*Normalized percentages are presented in parentheses, number of unique briefings

and other weather information. On bad weather days, their conversations included TFRs, NOTAMs, winds aloft, and to a much lesser extent, thunderstorm activity, AIRMETs/SIGMETs, cloud tops, icing conditions, PIREPs, and ATC delays/flow control advisories.

A final analysis was performed to determine what effect receiving a preflight briefing had on the pilots' intentions to fly. The data presented in Table 6 show that 31 GA pilots changed their flight plans after talking with AFSS specialists. Whether by asking for additional information or receiving weather information from AFSS specialists, the pilots decided that it was best to change their flight plans. Some delayed (46.9\%), postponed, or cancelled $(15.6 \%)$ their flights while others looked for alternate routes and destination points (15.6\%). This result shows that about $10 \%$ of the time, AFSS information positively affected the decision-making process, influenced pilot actions, and in these cases may have helped them avoid weather-related flight incidents.

Upon further investigation, for 22 of the filed flight plans, the AFSS specialist advised the pilot that a VFR flight was not recommended. Approximately $86 \%$ of these recommendations went to pilots who had filed VFR flight plans. Among this group of pilots, all but 27\% changed their flight plan. For pilots who filed IFR flight plans, all but $9 \%$ decided to change their flight plans. Of the pilots who changed their IFR flight plans, there was not enough information to record their outcomes/determine their future plans.

\section{DISCUSSION}

We all know that weather is often cited as a factor in aviation accidents and mishaps. Given that weather is a prominent force, it is not surprising that the type of weather information requested from, or provided by,
AFSS specialists is dependent on weather conditions at the time the preflight briefing occurs. We expect AFSS specialists to provide more weather information during periods of adverse weather. Likewise, we would not expect an AFSS specialist to provide thunderstorm activity to a GA pilot when there was no thunderstorm activity forecast anywhere in, or around, the vicinity of where the flight was to take place.

The purpose of the voice tape analysis was to document the types of weather information that pilots requested and how they might use that information. In particular, preflight standard, abbreviated, and outlook weather briefings representing a good, typical, and bad weather day occurring around the area serviced by an AFSS in the Midwest Mountain, Southwest, and New England Regions were obtained and reviewed. Of primary interest was the weather information relayed by AFSS specialists to the pilot and the pilot's comprehension and use of this information. Of lesser interest, but still important, was information concerning special use airspace (military training areas, MTRs; military operations areas MOAs; and temporary flight restrictions, TFRs).

We noted some differences among the facilities and AFSS specialists. In particular, the facilities differed in type of weather (based on their geographical location), special use airspace, terrain, requests for AFIS, requests for PIREPs, and their familiarity with the local flying public. The specialists differed mostly in the order in which they delivered weather items - although all of them seemed to follow closely the briefing guide presented in FAAO 7110.10R Flight Services. They also differed in their requests for PIREPs, suggestions to use EFAS (Flight Watch), the amount of verbiage spent to relay the briefing, and the amount of verbiage received from pilots.

Some of the pilots declined a weather briefing. They did not specify their reasons to the AFSS specialists. We 
can speculate that with the currently available technology (e.g., Internet aviation weather services and DUATS) these pilots felt they could adequately self-brief themselves on the weather. Even among the pilots who did not request a briefing, once they started talking with the AFSS specialists, they asked questions - they were searching for additional information that would lead to a safer and more satisfying flight experience. For example, marginal VFR conditions with sky conditions at 1500 broken overcast, visibility 3 miles, light rain showers in the area, may have challenged the pilot's skills; while 2500 broken overcast, visibility $5+$ miles, may have been within his or her comfort zone. (The former information may have led some pilots to decide not to fly, while the latter did not.) During typical weather conditions, pilots who did not request a preflight briefing still asked the AFSS specialist about the weather conditions at their departure point $(25 \%)$, en route $(25 \%)$, and at the destination point (25\%). On marginal VFR days, they also asked about anyTFRs, NOTAMs, AIRMETs/SIGMETs, and PIREPs as well as thunderstorm activity, winds aloft, cloud tops, ATC delays, and flow control advisories.

Notably, after hearing a preflight briefing many of the pilots made a determination as to whether to continue, delay or otherwise postpone, or cancel their intended flights. Sometimes the weather at the local AFSS was good but the weather conditions either en route or at the destination point were problematic. Delaying a departure could result in the pilot missing the weather. For others, a change in either the route or arrival airport, or changing from a VFR to an IFR flight plan allowed some of them to continue with their plans. Most important, the majority of the pilots who listened to the preflight briefing based their decisions on the best available information.

Always of concern were the few pilots who ignored the AFSS advice that "VFR Flight Not Recommended." The AFSS specialists issued this recommendation based on the observed or forecast conditions provided to them by the National Weather Service. In spite of having

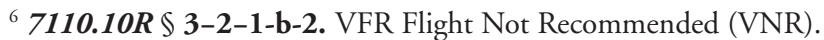
Include this statement when VFR flight is proposed and sky conditions or visibilities are present or forecast, surface or aloft, that in your judgment would make flight under visual flight rules doubtful. Describe the conditions, affected locations, and times. EXAMPLE - "There are broken clouds along the entire route between niner and one one thousand feet at the present time. With the approach of a cold front, these clouds are forecast to become overcast and to lower to below seven thousand with mountains and passes becoming obscured. V-F-R flight is not recommended between Salt Lake City and Grand Junction after two two zero zero ZULU." "V-F-R flight is not recommended in the Seattle area until early afternoon. The current weather at Seattle is indefinite ceiling three hundred sky obscured, visibility one, mist, and little improvement is expected before one eight zero zero ZULU." NOTE - This recommendation is advisory in nature. The decision as to whether the flight can be conducted safely rests solely with the pilot.
}

received a preflight weather briefing, the AFSS specialists' recommendation that VFR flight not recommended, and possibly other real-time, readily available weather sources and information, these pilots chose not to listen. They were aware of the risks yet made the deliberate decision to fly anyway. We do not know why. ${ }^{7}$

There have certainly been times when VFR pilots flew successfully into IFR conditions that raised their levels of confidence, allowing them to take on increasingly more challenging weather conditions (Goh and Wiegmann, 2001). In fact, Goh, Wiegmann, and O'Hara (2002) reported that in their simulation study, pilots' previous flight experience affected their situational assessment and risk perception. In a follow-on simulation study Goh, Weigmann, and O'Hare (2002) found that in some instances experience aided in diagnosing weather conditions - more experienced pilots may be more likely to divert from flight into adverse weather. In other cases experience altered pilots' perceptions as to their abilities - that is, it increased pilot confidence. Consequently, it reduced perceived risk and promoted VFR flight into IMC. What is missing are data to determine how often this actually happens and oversight to break this type of accident chain.

What we do know is that most aviation fatalities and mishaps are preventable in light of the information provided by the AFSS. The accident reports indicate that flight in IMC conditions by VFR-only pilots, or instrument rated pilots not on IFR flight plans, poses a significant threat of loss of aircraft control, controlled flight into terrain and presents a hazard to other IFR aircraft that may be authorized to be in the vicinity (AOPA 2005). The conclusions drawn from the analysis of fatal weather accidents and events related to weather encounters indicates that timely dissemination of adverse weather information is a key factor to preventing weather encounters (Lenz, personal communication).

The following recommendations are suggested to all general aviation pilots:

\footnotetext{
Personal communication with Doug Pearson led him to provide the following insights that were derived from reviewing six years of NTSB accident data. He suggested that pilots who fly after being told "VFR Flight Not Recommended" by AFSS specialists may do so for the following reasons: 1) They were in a hurry, had urgent business to attend to or an appointment that they could not miss and pressed on despite IFR conditions. 2) They were experienced pilots and had flown through IFR conditions many times before and been able to fly successfully... thus slowly building up a level of confidence that allowed them to take on increasingly worse weather conditions. 3) They had flown many times before when the forecast was for IFR (weather forecasts are often slanted towards the worst possible conditions to ensure all aspects of the situation are covered from the aviation weather forecaster's perspective) and they neither experienced IFR conditions nor were weather conditions as bad as previously forecast. So they pressed on even when IFR was forecast, believing that the weather would not be as bad as predicted.
} 
1) When calling into an AFSS, let the specialist know if you are new to the area or unfamiliar with the typical weather patterns. The specialist's familiarity with the local flying public and area specifics provides you with the added benefit of receiving information not available elsewhere.

2) During the preflight weather briefing, pay particular attention to differences in weather conditions at the departure point, en route, and destination. Although you may know what it is like to fly in your home town, your experience with weather in different localities may prove to be beyond your skill or comfort level.

3) While receiving a preflight weather briefing, let the specialist know if you need additional information, more detailed information or need clarification of some part of that briefing. That information may lead to a safer and more satisfying flight experience.

4) After receiving the preflight weather briefing, the most important decision you must make is whether or not to fly. If marginal visual flight conditions or adverse weather are factors, it may be best to delay, postpone, or cancel the flight or consider alternate routes and destination points.

5) Deciding to fly when the AFSS specialist indicates that "VFR flight not recommended" presents a significant risk. Before take-off, call the local AFSS and receive a weather update. Since your last preflight briefing, there could be significant weather changes that could adversely impact the safety and comfort of your flight along your filed route and at your destination point. Remember, 661 accidents in the USA occurred between 1990-present where VFR into IMC was identified as a "cause or factor" by the NTSB. Of these, $80 \%$ resulted in a fatality. ${ }^{8}$

6) While in flight, call into Flight Watch for the current weather conditions. You also can receive an FSSrecorded weather broadcast. These weather services can provide you with accurate weather information to aid your decision-making, should weather become a threat. As pointed out by Lenz, an analysis of 586 recent fatal weather accidents indicated that only 19 pilots had updated their weather information through FSS/AFSS.

Unlike travelers from the past who relied solely on naturally occurring moon and sky conditions to predict local weather, modern day travelers have real-time weather information. For example, earlier travelers learned that a red sky at dusk indicated that the following day would probably be dry and fine for travel. They didn't know that

${ }^{8}$ Data downloaded from the NTSB accident database. Data extraction and computation provided by Cristy Detwiler under the direction of Dr. Carla Hackworth. the evening sky's redness resulted from the sun shining through dust particles that were being pushed ahead of a high pressure system bringing in dry air. They also learned that a red sky at dawn was a fair indication that a storm was approaching. It took centuries for people to learn that the sky's redness at dawn resulted from an approaching low pressure system carrying a lot of moisture in the air. And that moisture could become rain, snow, sleet, or hail (depending upon season and geographical location).

Like these early travelers, we can still look up at the sky to predict local weather conditions. Unlike early travelers, we also have very sophisticated and technologically advanced tools that experts use to provide us with current and future weather information. Luckily, a multitude of weather-providers are available with stateof-the-art forecasting tools to supplement GA pilots simple act of looking up at the sky and reading the local sky conditions.

However, technological progress does not necessarily equate to improved safety. Although improvements in weather detection and forecasting capability have occurred, this information may not be available to GA pilots who are in flight. Likewise, if weather information is available, it may not be received in the cockpit in a timely manner for pilots to make safe decisions. In still other cases, the pilots may have received timely and accurate information but did not understand its implication regarding the safety of flight. As Lenz pointed out, simple misunderstandings regarding weather information have led to fatal accidents

Both early travelers and GA pilots share a common thread - they must decide whether to go or stay home in light of the information available at the time. This simple choice is a primary human factor that can result in safe or unsafe acts. As much as the FAA's primary mission is to promote safety and the FAA has reduced GA accidents by $12 \%$ over the last 5 years (AOPA 2005), the study into causal and contributing factors related to weather accidents offers an opportunity to reduce the largest cause of aviation fatalities - VFR flight into IMC.

\section{REFERENCES}

Aircraft Owners and Pilots Association (2005). Nall Report-Accident trends and factors for 2004. www. aopa.org/asf/publications/nall.html. Accessed 9 January, 2007.

Bible, Revised Standard. Matthew, from The holy Bible, Revised Standard version. Electronic Text Center, University of Virginia Library. etext.lib.virginia. edu/rsv.browse.html. Accessed 9 January, 2007. 
Driskill, W.E., Weissmuller, J.J., Quebe, J., Hand, D.K., Dittmar, M.J., and Hunter, D.R. (1997). The use of weather information in aeronautical decision-making. Report no. DOT/FAA/AM-97/3. Washington, DC: Federal Aviation Administration.

Federal Aviation Administration (1995a). 7110.10R Flight Services. www.faa.gov/ATPUBS/FSS/INDEX.HTM. Accessed 9 January, 2007.

Goh, J., Wiegmann, D., and O'Hare, D. (2002). The effects of distance traveled and pilot experience on pilot's decisions to continue visual flight rules flight into adverse weather. Aviation, Space, and Environmental Medicine, 73(3), 252-3.

Goh, J. and Wiegmann, D. A. (2001). Visual flight rules flight (VFR) into adverse weather: An empirical investigation of the possible causes. The International Journal of Aviation Psychology, 11, 359-79.

Knecht, W., Harris, H., and Shappell, S. (2005). The influence of visibility, cloud ceiling, financial incentive, and personality factors on general aviation pilots willingness to take off into marginal weather, Part I: The data and preliminary conclusions. Report no. DOT/FAA/AM-05/7. Washington, DC: Federal Aviation Administration.

National Transportation Safety Board. (1968). An analysis of U.S. general aviation accidents involving weather as a causelrelated factor 1966, Notation 155. Washington, DC: Author.
National Transportation Safety Board. (1974). Special study of fatal, weather-involved general aviation accidents. Report no. NTSB-AAS-74-2. Washington, DC:Author. www.amelia.db.erau.edu/reports/ntsb/ aas/AAS74-02.pdf. Accessed 9 January, 2007.

National Transportation Safety Board. (1976). Non-fatal, weather-involved general aviation accidents. Report no. NTSB/AAS-76-3. Washington, DC: Author. www.amelia.db.erau.edu/reports/ntsb/aas/AAS7603.pdf. Accessed 9 January, 2007.

National Transportation Safety Board. (1989). General aviation accidents involving VFR flight into IMC. Report no. NTSB/SR-89-01. Washington, DC: Author. www.amelia.db.erau.edu/reports/ntsb/sr/ SR89-01.pdf. Accessed 9 January, 2007.

National Transportation Safety Board. (2005). Risk factors associated with weather-related general aviation accidents. Report no. NTSB/SS-05/01. Washington, DC: Author.

Pearson, D.C. (2002). VFRflight not recommended:Astudy of weather-related fatal aviation accidents. SR SSD 2002-18. Atlanta GA: NOAA/National Weather Service. www.srh.noaa.gov/topics/attach/html/ ssd02-18.htm. Accessed 9 January, 2007. 

APPENDIX A

AFSS Communication Database Codebook

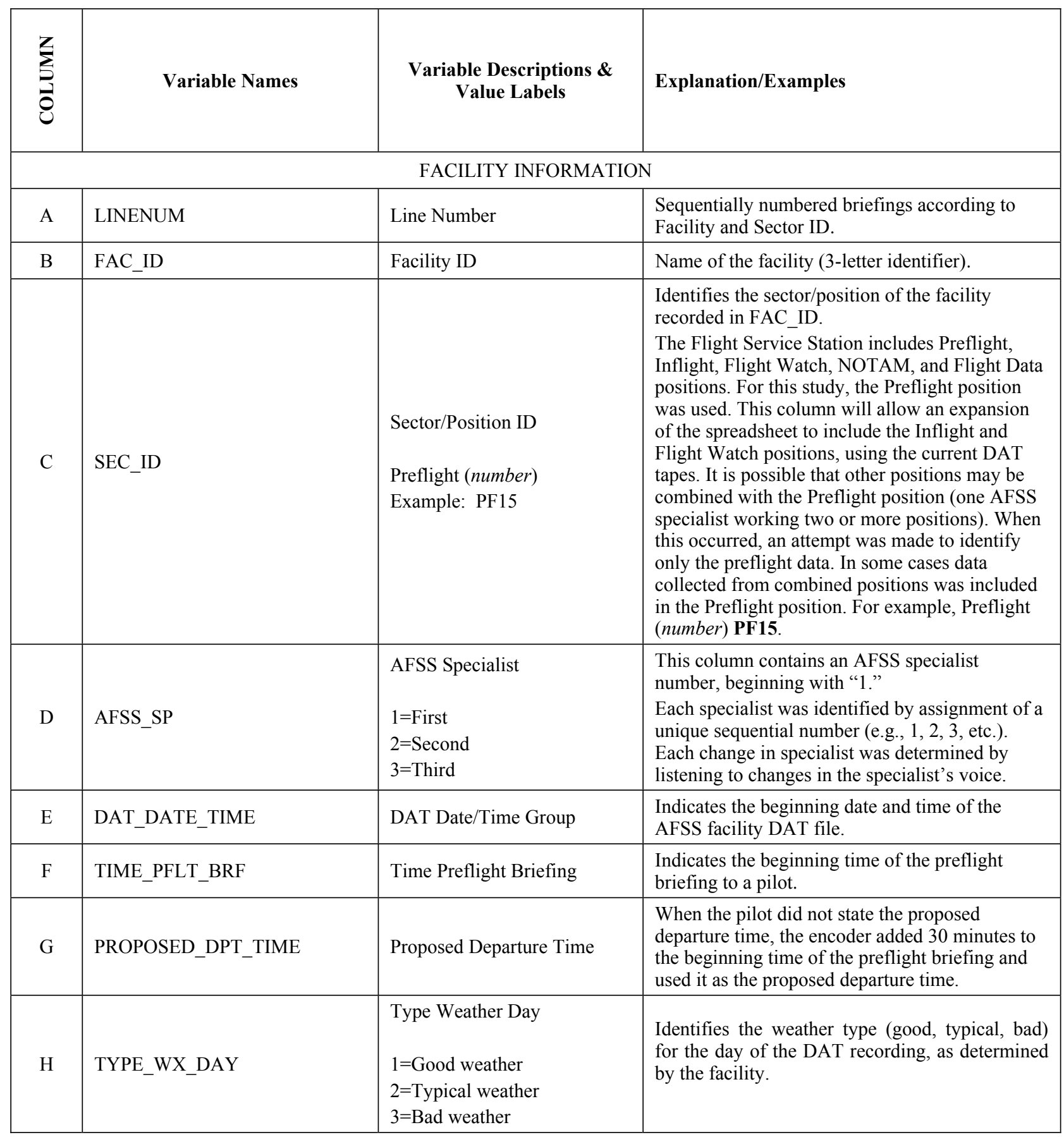




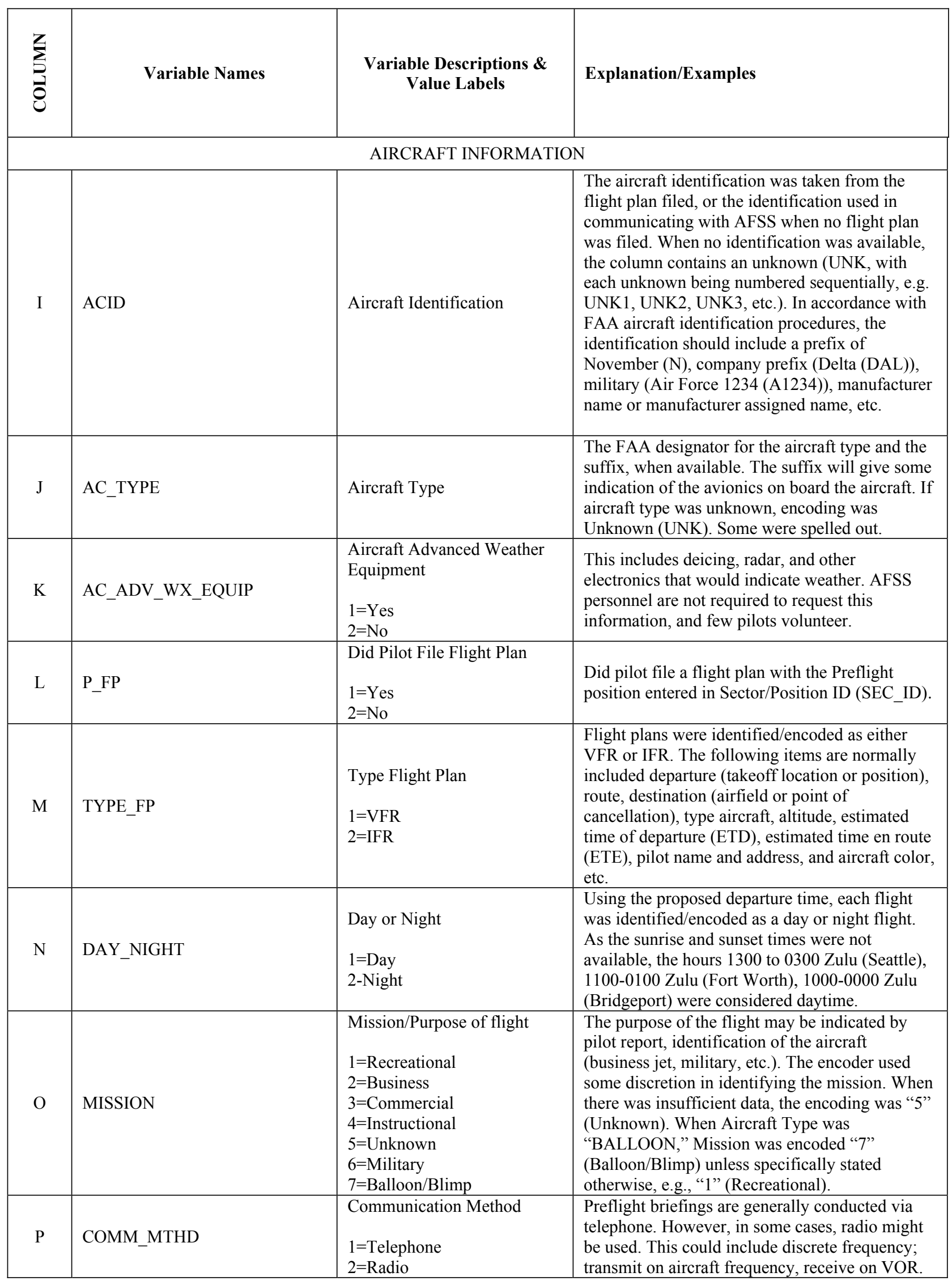


AFSS Communication Database Codebook (continued)

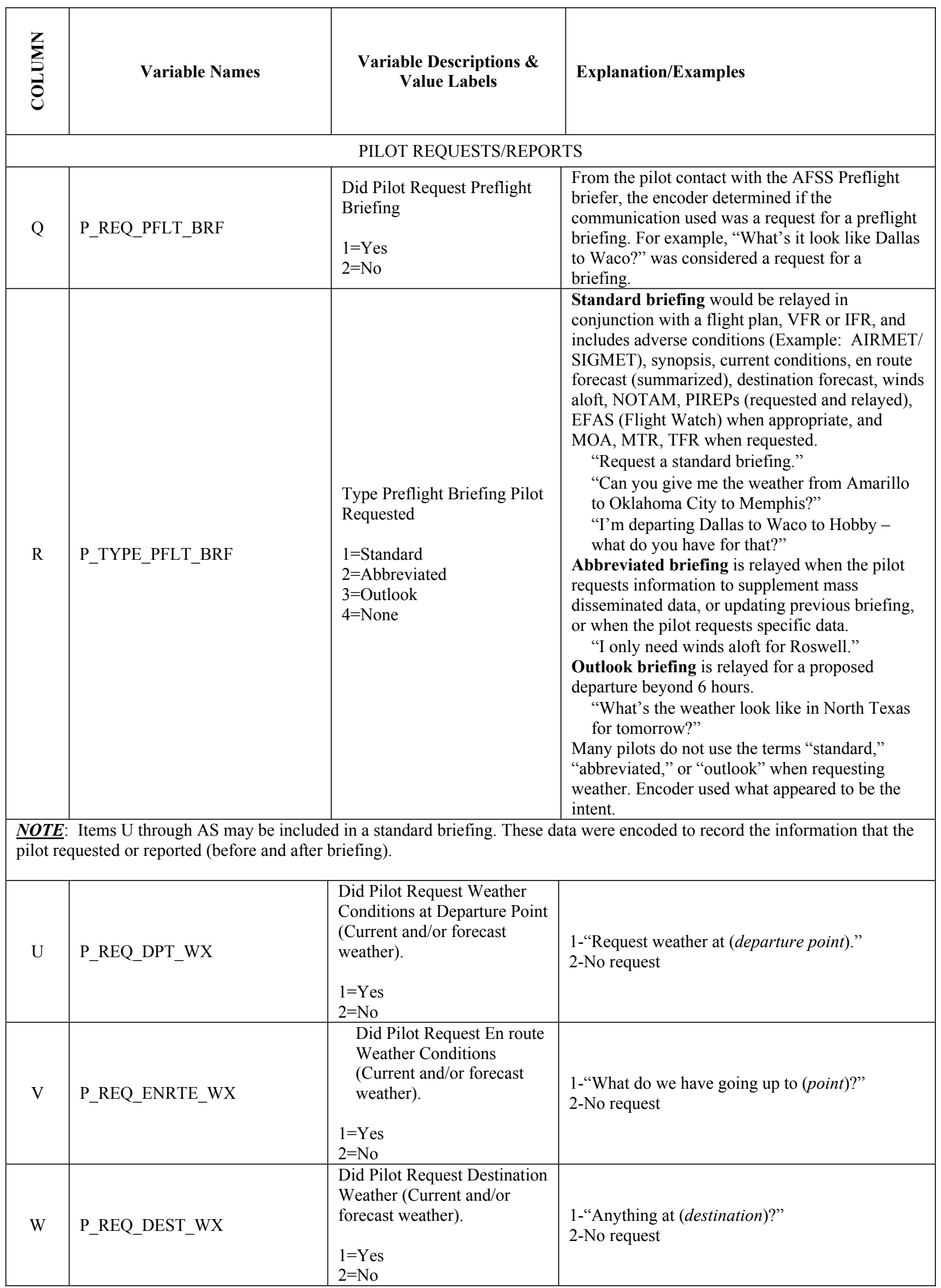


AFSS Communication Database Codebook (continued)

\begin{tabular}{|c|c|c|c|}
\hline 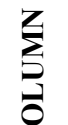 & Variable Names & $\begin{array}{l}\text { Variable Descriptions \& } \\
\text { Value Labels }\end{array}$ & Explanation/Examples \\
\hline \multicolumn{4}{|c|}{ PILOT REQUESTS/REPORTS } \\
\hline $\mathrm{X}$ & P_REQ_PIREP & $\begin{array}{l}\text { Did Pilot Request PIREP } \\
\begin{array}{l}1=\text { Yes } \\
2=\mathrm{No}\end{array}\end{array}$ & $\begin{array}{l}\text { 1-“Are there any PIREPs?" } \\
\text { 2-No request }\end{array}$ \\
\hline $\mathrm{Z}$ & P_REQ_TSTORM & $\begin{array}{l}\text { Did Pilot Request } \\
\text { Thunderstorm Activity } \\
1=\text { Yes } \\
2=\mathrm{No}\end{array}$ & $\begin{array}{l}\text { 1-Are there any thunderstorms in the area?" } \\
2-\text { No request }\end{array}$ \\
\hline AA & P_REQ_ICING & $\begin{array}{l}\text { Did Pilot Request Icing } \\
\text { Conditions } \\
1=\text { Yes } \\
2=\mathrm{No}\end{array}$ & $\begin{array}{l}\text { 1-“Any icing?" "What altitude?" } \\
\text { 2-No request }\end{array}$ \\
\hline $\mathrm{AB}$ & P_REQ_SURF_WND & $\begin{array}{l}\text { Did Pilot Request Surface } \\
\text { Winds } \\
1=\text { Yes } \\
2=\text { No }\end{array}$ & $\begin{array}{l}\text { 1-"What are the winds?" } \\
\text { 2-No request }\end{array}$ \\
\hline $\mathrm{AC}$ & P_REQ_WND_ALFT & $\begin{array}{l}\text { Did Pilot Request Winds } \\
\text { Aloft } \\
1=\text { Yes } \\
2=\text { No }\end{array}$ & $\begin{array}{l}\text { 1-"What are the winds aloft at six thousand and } \\
\text { nine thousand?" } \\
\text { 2-No request }\end{array}$ \\
\hline $\mathrm{AD}$ & P_REQ_SKYCOND & $\begin{array}{l}\text { Did Pilot Request Sky } \\
\text { Conditions (Clouds) } \\
1=\text { Yes } \\
2=\mathrm{No}\end{array}$ & $\begin{array}{l}\text { 1-"What are the clouds scattered or broken?" } \\
\text { 2-No request }\end{array}$ \\
\hline $\mathrm{AE}$ & P_REQ_CLD_TP & $\begin{array}{l}\text { Did Pilot Request Cloud Tops } \\
\begin{array}{l}1=\text { Yes } \\
2=\text { No }\end{array}\end{array}$ & $\begin{array}{l}\text { 1-"What are the tops?" } \\
\text { 2-No request }\end{array}$ \\
\hline $\mathrm{AF}$ & P_REQ_PRECIP & $\begin{array}{l}\text { Did Pilot Request } \\
\text { Precipitation } \\
1=\text { Yes } \\
2=\mathrm{No}\end{array}$ & $\begin{array}{l}\text { 1-“Any rain?" } \\
\text { 2-No request }\end{array}$ \\
\hline AG & P_REQ_PRECIP_INTNS & $\begin{array}{l}\text { Did Pilot Request } \\
\text { Precipitation Intensity } \\
1=\text { Yes } \\
2=\mathrm{No}\end{array}$ & $\begin{array}{l}\text { 1-“Is the snow heavy or light?" } \\
\text { 2-No request }\end{array}$ \\
\hline $\mathrm{AH}$ & P_REQ_VIS & $\begin{array}{l}\text { Did Pilot Request Visibility } \\
\begin{array}{l}1=\mathrm{Yes} \\
2=\mathrm{No}\end{array}\end{array}$ & $\begin{array}{l}\text { 1-"What is the visibility at (point)?" } \\
\text { 2-No request }\end{array}$ \\
\hline
\end{tabular}


AFSS Communication Database Codebook (continued)

\begin{tabular}{|c|c|c|c|}
\hline$\sum_{0}^{2}$ & Variable Names & $\begin{array}{l}\text { Variable Descriptions \& } \\
\text { Value Labels }\end{array}$ & Explanation/Examples \\
\hline AI & P_REQ_VIS_OBSCUR & $\begin{array}{l}\text { Did Pilot Request Visibility } \\
\text { Obscuration } \\
1=\text { Yes } \\
2=\mathrm{No}\end{array}$ & $\begin{array}{l}\text { 1-“Is that smoke from fires or just haze?" } \\
\text { 2-No request }\end{array}$ \\
\hline $\mathrm{AJ}$ & P_REQ_TEMP & $\begin{array}{l}\text { Did Pilot Request } \\
\text { Temperature } \\
1=\text { Yes } \\
2=\mathrm{No}\end{array}$ & $\begin{array}{l}\text { 1-“What is the temperature today?" } \\
\text { 2-No request }\end{array}$ \\
\hline AK & P_REQ_DEWPT & $\begin{array}{l}\text { Did Pilot Request Dew Point } \\
\begin{array}{l}1=\text { Yes } \\
2=\mathrm{No}\end{array}\end{array}$ & $\begin{array}{l}\text { 1-"What is the dew point?" } \\
\text { 2-No request }\end{array}$ \\
\hline AL & P_REQ_ALTM & $\begin{array}{l}\text { Did Pilot Request Altimeter } \\
1=\mathrm{Yes} \\
2=\mathrm{No}\end{array}$ & $\begin{array}{l}\text { 1-“Say Phoenix altimeter." } \\
\text { 2-No request }\end{array}$ \\
\hline AM & P_REQ_OTR_WX & $\begin{array}{l}\text { Did Pilot Request Other } \\
\text { Weather } \\
1=\text { Yes } \\
2=\mathrm{No}\end{array}$ & $\begin{array}{l}\text { 1-“Is there anything else that might help?" } \\
\text { 2-No request }\end{array}$ \\
\hline AN & P_REQ_NOTAM & $\begin{array}{l}\text { Did Pilot Request NOTAMs } \\
\begin{array}{l}1=\mathrm{Yes} \\
2=\mathrm{No}\end{array}\end{array}$ & $\begin{array}{l}\text { 1-“Do you have NOTAMs along my route?" } \\
\text { 2-No request }\end{array}$ \\
\hline $\mathrm{AO}$ & P_REQ_TFR & $\begin{array}{l}\text { Did Pilot Request TFRs } \\
\begin{array}{l}1=\text { Yes } \\
2=\mathrm{No}\end{array}\end{array}$ & $\begin{array}{l}\text { 1-"Is the temporary restriction at Dallas still in } \\
\text { effect?" } \\
\text { 2-No request }\end{array}$ \\
\hline AP & P_REQ_MOA_MTR & $\begin{array}{l}\text { Did Pilot Request MOA or } \\
\text { MTR } \\
1=\text { Yes } \\
2=\text { No }\end{array}$ & $\begin{array}{l}\text { 1-“Is the Pecos MOA open?" } \\
\text { 2-No request }\end{array}$ \\
\hline AQ & P_REQ_AIRMET_SIGMET & $\begin{array}{l}\text { Did Pilot Request } \\
\text { AIRMET/SIGMET } \\
1=\text { Yes } \\
2=\mathrm{No}\end{array}$ & $\begin{array}{l}\text { 1-“No SIGMETs today?" } \\
\text { 2-No request }\end{array}$ \\
\hline AR & P_REQ_ATC_DEL_FC_ADV & $\begin{array}{l}\text { Did Pilot Request ATC } \\
\text { Delays or Flow Control } \\
\text { Advisories } \\
1=\text { Yes } \\
2=\mathrm{No}\end{array}$ & \\
\hline Y & P_RPT_PIREP & $\begin{array}{l}\text { Did Pilot Report PIREP } \\
\begin{array}{l}1=\text { Yes } \\
2=\mathrm{No}\end{array}\end{array}$ & $\begin{array}{l}\text { 1-"The tops of clouds are ten thousand two } \\
\text { hundred." } \\
\text { 2-No report }\end{array}$ \\
\hline AS & P_RPT_AFIS & $\begin{array}{l}\text { Did Pilot Report Having } \\
\text { Automated Flight Information } \\
\text { Service } \\
1=\text { Yes } \\
2=\mathrm{No}\end{array}$ & \\
\hline
\end{tabular}




\begin{tabular}{|c|c|c|c|}
\hline \multirow{2}{Z}{} & Variable Names & $\begin{array}{c}\text { Variable Descriptions \& } \\
\text { Value Labels }\end{array}$ & Explanation/Examples \\
\hline \multicolumn{3}{|c|}{} & AFSS PREFLIGHT INFORMATION
\end{tabular}

NOTE: Items AT through BS were encoded if they were relayed or requested by the AFSS briefer during the preflight briefing, or as a reply to a pilot request, i.e., any information within these categories was encoded.

\begin{tabular}{|c|c|c|c|}
\hline S & AFSS_ISSUES_PFLT_BRF & $\begin{array}{l}\text { Did AFSS Issue Preflight } \\
\text { Briefing } \\
1=\text { Yes } \\
2=\mathrm{No}\end{array}$ & \\
\hline $\mathrm{T}$ & AFSS_TYPE_PFLT_BRF & $\begin{array}{l}\text { Type Preflight Briefing } \\
\text { AFSS Issued } \\
1=\text { Standard } \\
2=\text { Abbreviated } \\
3=\text { Outlook } \\
4=\text { None }\end{array}$ & $\begin{array}{l}\text { The preflight briefing types were taken from FAA } \\
\text { Order } 7110.10 \text { R subpara } 3-2-1 \text { : } \\
\text { Standard briefing would be relayed in } \\
\text { conjunction with a flight plan, VFR or IFR, and } \\
\text { includes adverse conditions (Example: AIRMET/ } \\
\text { SIGMET), synopsis, current conditions, en route } \\
\text { forecast (summarized), destination forecast, } \\
\text { winds aloft, NOTAM, PIREPs (requested and } \\
\text { relayed), EFAS (Flight Watch) when appropriate, } \\
\text { and MOA, MTR, TFR when requested. } \\
\text { Abbreviated briefing is relayed when the pilot } \\
\text { requests information to supplement mass } \\
\text { disseminated data, or updating previous briefing, } \\
\text { or when the pilot requests specific data. } \\
\text { Outlook briefing is relayed for a proposed } \\
\text { departure beyond } 6 \text { hours. }\end{array}$ \\
\hline AT & AFSS_REL_ADVRS_COND & $\begin{array}{l}\text { Did AFSS Relay Adverse } \\
\text { Conditions } \\
1=\text { Yes } \\
2=\mathrm{No}\end{array}$ & \\
\hline $\mathrm{AU}$ & AFSS_REL_WX_SYN & $\begin{array}{l}\text { Did AFSS Relay Weather } \\
\text { Synopsis } \\
1=\text { Yes } \\
2=\mathrm{No}\end{array}$ & \\
\hline AV & AFSS_REL_DPT_WX & $\begin{array}{l}\text { Did AFSS Relay Weather } \\
\text { Conditions at Departure Point } \\
\text { (Current and/or forecast } \\
\text { weather). } \\
1=\text { Yes } \\
2=\text { No }\end{array}$ & $\begin{array}{l}\text { Current and/or forecast weather. } \\
\text { 1-"Yuma shows few clouds at fifteen hundred } \\
\text { wind two eight zero at ten gusting to fifteen } \\
\text { visibility ten or more altimeter two nine nine } \\
\text { three." } \\
\text { 2-No relay }\end{array}$ \\
\hline AW & AFSS_REL_ENRTE_WX & $\begin{array}{l}\text { Did AFSS Relay En route } \\
\text { Weather Conditions (Current } \\
\text { and/or forecast weather). } \\
1=\text { Yes } \\
2=\mathrm{No}\end{array}$ & $\begin{array}{l}\text { Current and/or forecast weather. } \\
\text { 1-"Looks like you'll be east of any weather the } \\
\text { winds at seven thousand are one three five at six } \\
\text { at nine thousand one six zero at eight clear below } \\
\text { twelve thousand." } \\
\text { 2-No relay }\end{array}$ \\
\hline $\mathrm{AX}$ & AFSS_REL_DEST_WX & $\begin{array}{l}\text { Did AFSS Relay Destination } \\
\text { Weather (Current and/or } \\
\text { forecast weather). } \\
1=\text { Yes } \\
2=\text { No }\end{array}$ & $\begin{array}{l}\text { Current and/or forecast weather. } \\
\text { 1-"Your ETA at Roswell about one four three } \\
\text { zero it will be one five thousand broken visibility } \\
\text { fifteen winds north three five zero at one one } \\
\text { knots." } \\
\text { 2-No relay }\end{array}$ \\
\hline
\end{tabular}


AFSS Communication Database Codebook (continued)

\begin{tabular}{|c|c|c|c|}
\hline$\sum_{\substack{1 \\
0}}^{Z}$ & Variable Names & $\begin{array}{l}\text { Variable Descriptions \& } \\
\text { Value Labels }\end{array}$ & Explanation/Examples \\
\hline AY & AFSS_REL_PIREP & $\begin{array}{l}\text { Did AFSS Relay PIREP } \\
\begin{array}{l}1=\text { Yes } \\
2=\mathrm{No}\end{array}\end{array}$ & $\begin{array}{l}\text { 1-“PIREP tops ten thousand two hundred." } \\
\text { 2-No relay }\end{array}$ \\
\hline $\mathrm{AZ}$ & AFSS_REQ_PIREP & $\begin{array}{l}\text { Did AFSS Request PIREP } \\
\begin{array}{l}1=\mathrm{Yes} \\
2=\mathrm{No}\end{array}\end{array}$ & $\begin{array}{l}\text { 1-“We could use a PIREP if you're going over to } \\
\text { Denver." } \\
\text { 2-No request }\end{array}$ \\
\hline $\mathrm{BA}$ & AFSS_REL_TSTORM & $\begin{array}{l}\text { Did AFSS Relay } \\
\text { Thunderstorm Activity } \\
1=\text { Yes } \\
2=\mathrm{No}\end{array}$ & $\begin{array}{l}\text { 1-“"The front has passed and thunderstorm } \\
\text { dissipated." } \\
\text { 2-No relay }\end{array}$ \\
\hline $\mathrm{BB}$ & AFSS_REL_ICING & $\begin{array}{l}\text { Did AFSS Relay Icing } \\
\text { Conditions } \\
1=\text { Yes } \\
2=\mathrm{No}\end{array}$ & $\begin{array}{l}\text { 1-"No icing." "Light clear ice at nine thousand." } \\
\text { 2-No relay }\end{array}$ \\
\hline $\mathrm{BC}$ & AFSS_REL_SURF_WND & $\begin{array}{l}\text { Did AFSS Relay Surface } \\
\text { Winds } \\
1=\text { Yes } \\
2=\mathrm{No}\end{array}$ & $\begin{array}{l}\text { 1-“Two nine zero at twelve." } \\
\text { 2-No relay }\end{array}$ \\
\hline $\mathrm{BD}$ & AFSS_REL_WND_ALOFT & $\begin{array}{l}\text { Did AFSS Relay Winds Aloft } \\
\begin{array}{l}1=\text { Yes } \\
2=\text { No }\end{array}\end{array}$ & $\begin{array}{l}\text { 1-"Nine thousand two seven zero at ten twelve } \\
\text { thousand two eight zero at eighteen." } \\
\text { 2-No relay }\end{array}$ \\
\hline $\mathrm{BE}$ & AFSS_REL_SKYCOND & $\begin{array}{l}\text { Did AFSS Relay Sky } \\
\text { Conditions (Clouds) } \\
1=\text { Yes } \\
2=\mathrm{No}\end{array}$ & $\begin{array}{l}\text { 1-“"Twenty five hundred broken three thousand } \\
\text { overcast." } \\
\text { 2-No relay }\end{array}$ \\
\hline $\mathrm{BF}$ & AFSS_REL_CLD_TP & $\begin{array}{l}\text { Did AFSS Relay Cloud Tops } \\
\begin{array}{l}1=\text { Yes } \\
2=\mathrm{No}\end{array}\end{array}$ & $\begin{array}{l}\text { 1-“A PIREP here by a one eighty two says tops } \\
\text { are nine thousand five hundred." } \\
\text { 2-No relay }\end{array}$ \\
\hline BG & AFSS_REL_PRECIP & $\begin{array}{l}\text { Did AFSS Relay } \\
\text { Precipitation } \\
1=\text { Yes } \\
2=\mathrm{No}\end{array}$ & $\begin{array}{l}\text { 1-"No rain in vicinity." "A drizzle over the east } \\
\text { Cascades." } \\
\text { 2-No relay }\end{array}$ \\
\hline $\mathrm{BH}$ & AFSS_REL_PRECIP_INTNS & $\begin{array}{l}\text { Did AFSS Relay } \\
\text { Precipitation Intensity } \\
1=\mathrm{Yes} \\
2=\mathrm{No}\end{array}$ & $\begin{array}{l}\text { 1-“Light rain shower ten north of Puttman." } \\
\text { 2-No relay }\end{array}$ \\
\hline BI & AFSS_REL_VIS & $\begin{array}{l}\text { Did AFSS Relay Visibility } \\
\begin{array}{l}1=\text { Yes } \\
2=\mathrm{No}\end{array}\end{array}$ & $\begin{array}{l}\text { 1-"Visibility clear below eight thousand." } \\
\text { "Visibility ten." } \\
\text { 2-No relay }\end{array}$ \\
\hline BJ & AFSS_REL_VIS_OBSCUR & $\begin{array}{l}\text { Did AFSS Relay Visibility } \\
\text { Obscuration } \\
1=\text { Yes } \\
2=\mathrm{No}\end{array}$ & $\begin{array}{l}\text { 1-"Smoke from the fire east side of the } \\
\text { mountain." } \\
\text { 2-No relay }\end{array}$ \\
\hline
\end{tabular}


AFSS Communication Database Codebook (continued)

\begin{tabular}{|c|c|c|c|}
\hline$\sum_{\substack{\zeta \\
ٍ}}^{Z}$ & Variable Names & $\begin{array}{l}\text { Variable Descriptions \& } \\
\text { Value Labels }\end{array}$ & Explanation/Examples \\
\hline BK & AFSS_REL_TEMP & $\begin{array}{l}\text { Did AFSS Relay } \\
\text { Temperature } \\
\begin{array}{l}1=\mathrm{Yes} \\
2=\mathrm{No}\end{array} \\
\end{array}$ & $\begin{array}{l}\text { 1-"Hot today. Surface temperature fifty two } \\
\text { twelve thousand forty two." } \\
\text { 2-No relay }\end{array}$ \\
\hline $\mathrm{BL}$ & AFSS_REL_DEWPT & $\begin{array}{l}\text { Did AFSS Relay Dew Point } \\
\begin{array}{l}1=\text { Yes } \\
2=\text { No }\end{array}\end{array}$ & $\begin{array}{l}\text { 1-“"The dew point is forty two." } \\
\text { 2-No relay }\end{array}$ \\
\hline $\mathrm{BM}$ & AFSS_REL_ALTM & $\begin{array}{l}\text { Did AFSS Relay Altimeter } \\
\begin{array}{l}1=\text { Yes } \\
2=\text { No }\end{array}\end{array}$ & $\begin{array}{l}\text { 1-“Seattle altimeter two nine nine two." } \\
\text { 2-No relay }\end{array}$ \\
\hline $\mathrm{BN}$ & AFSS_REL_OTR_WX & $\begin{array}{l}\text { Did AFSS Relay Other } \\
\text { Weather } \\
1=\text { Yes } \\
2=\text { No }\end{array}$ & $\begin{array}{l}\text { 1-"Look for some turbulence going over the } \\
\text { mountain range." } \\
\text { 2-No relay }\end{array}$ \\
\hline $\mathrm{BO}$ & AFSS_REL_NOTAM & $\begin{array}{l}\text { Did AFSS Relay NOTAMs } \\
\begin{array}{l}1=\text { Yes } \\
2=\text { No }\end{array}\end{array}$ & $\begin{array}{l}\text { 1-"We have a NOTAM that Seattle VOR is out of } \\
\text { service today until fourteen hundred." } \\
\text { 2-No relay }\end{array}$ \\
\hline BP & AFSS_REL_TFR & $\begin{array}{l}\text { Did AFSS Relay TFRs } \\
\begin{array}{l}1=\text { Yes } \\
2=\text { No }\end{array}\end{array}$ & $\begin{array}{l}\text { 1-“The flight restriction around the fire east of } \\
\text { Puttman has expired." } \\
\text { 2-No relay }\end{array}$ \\
\hline BQ & AFSS_REL_MOA_MTR & $\begin{array}{l}\text { AFSS Relay MOA or MTR } \\
\begin{array}{l}1=\text { Yes } \\
2=\text { No }\end{array}\end{array}$ & $\begin{array}{l}\text { 1-"The Pecos MOA is active zero eight zero zero } \\
\text { to one six zero zero local daily." } \\
\text { 2-No relay }\end{array}$ \\
\hline BR & AFSS_REL_AIRMET_SIGMET & $\begin{array}{l}\text { Did AFSS Relay } \\
\text { AIRMET/SIGMET } \\
1=\text { Yes } \\
2=\mathrm{No}\end{array}$ & $\begin{array}{l}\text { 1-“SIGMET has been issued for thunderstorms } \\
\text { and low visibility in the area of Albuquerque." } \\
\text { 2-No relay }\end{array}$ \\
\hline BS & $\begin{array}{l}\text { AFSS_REL_ATC_DEL_FC_AD } \\
\mathrm{V}\end{array}$ & $\begin{array}{l}\text { Did AFSS Relay ATC Delays } \\
\text { or Flow Control Advisories } \\
1=\text { Yes } \\
2=\mathrm{No}\end{array}$ & \\
\hline BT & AFSS_AFIS & $\begin{array}{l}\text { Did AFSS Advise Current } \\
\text { Automated Flight } \\
\text { Information Service } \\
1=\text { Yes } \\
2=\text { No }\end{array}$ & \\
\hline BU & AFSS_VFR_NOT_REC & $\begin{array}{l}\text { Did AFSS State VFR Flight } \\
\text { Not Recommended } \\
\begin{array}{l}1=\text { Yes } \\
2=\mathrm{No}\end{array}\end{array}$ & $\begin{array}{l}\text { This requirement is included in preflight } \\
\text { briefings. However, it merits inclusion as a single } \\
\text { variable to be recorded/encoded. } \\
\text { 1-"VFR flight Durango to Crested Butte not } \\
\text { recommended." } \\
\text { 2-AFSS did not state VFR flight not } \\
\text { recommended. }\end{array}$ \\
\hline
\end{tabular}


AFSS Communication Database Codebook (continued)

\begin{tabular}{|c|c|c|c|}
\hline$\sum_{\substack{z \\
ٍ}}^{Z}$ & Variable Names & $\begin{array}{l}\text { Variable Descriptions \& } \\
\text { Value Labels }\end{array}$ & Explanation/Examples \\
\hline BV & P_CHG_FP & $\begin{array}{l}\text { Did Pilot Change Flight Plan } \\
1=\text { Yes-before preflight } \\
\text { briefing } \\
2=\text { Yes-after preflight briefing } \\
3=\text { No }\end{array}$ & $\begin{array}{l}\text { Flight plan or altitude change after receiving a } \\
\text { preflight briefing (standard or abbreviated). The } \\
\text { purpose of this data is for analysis of the actions } \\
\text { taken by a pilot after a preflight briefing. }\end{array}$ \\
\hline BW & P_CHG_ALT & $\begin{array}{l}\text { Did Pilot Change Altitude } \\
1=\text { Yes-before preflight } \\
\text { briefing } \\
2=\text { Yes-after preflight briefing } \\
3=\text { No }\end{array}$ & $\begin{array}{l}\text { Flight plan or altitude change after receiving a } \\
\text { preflight briefing (standard or abbreviated). The } \\
\text { purpose of this data is for analysis of the actions } \\
\text { taken by a pilot after a preflight briefing. }\end{array}$ \\
\hline BY & COMMENTS & Encoder (SME) Comments & $\begin{array}{l}\text { Pilot weather requests and AFSS weather } \\
\text { information relays that are out of the norm are } \\
\text { recorded for further study. }\end{array}$ \\
\hline $\mathrm{BZ}$ & PFLT_BRF_ANALYSIS & $\begin{array}{l}\text { Preflight Briefing for } \\
\text { Detailed Analysis } \\
\mathrm{Y}=\text { Yes }\end{array}$ & $\begin{array}{l}\text { Encoded "Y" if AFSS preflight briefing contains } \\
\text { information that merits detailed analysis. }\end{array}$ \\
\hline $\mathrm{CA}$ & P_CMTS_DAT & $\begin{array}{l}\text { Interesting Pilot Comments } \\
\text { (from DAT) }\end{array}$ & \\
\hline
\end{tabular}


